\title{
WEB 3.0 IN LEARNING ENVIRONMENTS: A SYSTEMATIC REVIEW
}

\author{
Dr. Esra ACIKGUL FIRAT \\ ORCID: 0000-0002-6401-1476 \\ Faculty of Education \\ Adiyaman University \\ Adiyaman, TURKEY \\ Dr. Selcuk FIRAT \\ ORCID: 0000-0002-2935-2929 \\ Faculty of Education \\ Adiyaman University \\ Adiyaman, TURKEY
}

Received: 22/01/2020 Accepted: 11/05/2020

\begin{abstract}
Web 3.0 technologies have inevitably affected educational research. Many studies have been conducted on the use of Web 3.0 tools in learning environments. The synthesis and summarization of the results of these studies with a systematic review is considered important in terms of being the source of future research and helping to spread the use of these technologies in education. Hence the purpose of this systematic review is to obtain a better understanding of how Web 3.0 technologies can be used to enhance quality of educational settings. The systematic analysis was conducted by 81 papers from 2005 to 2020. The PRISMA Statement was used in the research and report generation process. Papers related to semantic, augmented reality, intelligent tutoring system, $3 \mathrm{~d}$ visual environments, $3 \mathrm{~d}$ games and ontologies is included in the study. The results show that in 2008 and 2013 there was an increase in the number of studies. In addition, most experimental studies have been conducted in this literature and the studies in the discipline of science education are more than other disciplines. When the data collection tools used in the studies were examined, it was found that the majority of the studies were quantitative and most benefited from surveys, questionnaires and observational information in the data collection process. In addition, the majority of studies focus on the learning usefulness and learning outcomes of the software used in the research. Furthermore, suggestions for future researches were made in line with the limitations and results of the study.
\end{abstract}

Keywords: Systematic review, Semantic Web, augmented and virtual reality, intelligent tutoring systems.

\section{INTRODUCTION}

The concept of e-learning has emerged as a result of shifting of traditional teaching environments from to digital environments with the development of web technologies (Miranda, Isaias and Costa, 2014). With the continuous development of web technologies, e-learning environments have also changed. E-learning has recently become applicable and popular thanks to the rapid development of internet technology, especially in relation to web page interaction (Lee, Tsai \& Wang, 2006). When web technology entered our lives for the first time, there were websites where the flow of information was one-way, and users could not interfere with the information and only access information allowed by the administrators (Park, 2003; Thomas ve Li, 2008). This form of the Web, called Web 1.0, is only considered a "read-only" web with minimal interaction on websites (Dominic, Francis \& Pilomenraj, 2014). Then, there was a transition from a read-only form (Web 1.0) to a read-write form (Web 2.0) and with Web 2.0 technologies, users also play the role of authors. In this form of the Web, the social use of the web has come to the forefront and collaboration, allowing 
users to actively participate in content creation and to share information online (Grosseck, 2009). Web 2.0 tools have the potential to affect e-learning environments (Buffington, 2008). Web 2.0 technologies have greatly increased interaction with social inclusion, but with the progress of the Web, it has gone beyond interaction with knowledge. After this process, the meaning and personalization of the information has gained importance. This has led to the emergence of Web 3.0 technologies called semantic web. Semantic Web inherits the concepts of the World Wide Web and adds "meaning" to the Web that enables machines to understand the meaning of information (Berners-Lee, Hendler ve Lassila, 2001). Therefore, with the emergence of Web 3.0 technologies, the interactive world provided by Web 2.0 is made unique to people. Web 3.0 helps us to reach meaningful information by filtering out a lot of erroneous data for the needs of users in searches over the internet (Chisega-Negrilă, 2013). Therefore, the purpose of Web 3.0 tools is to provide a semantic web environment that enables users to access the information they need quickly and at any time (Miranda et al., 2014).

The advent of Web 3.0 applications and the reciprocal cyclic progress of science and technology have inevitably affected educational research. Many studies have been conducted on the use of Web 3.0 tools in education. The synthesis and summarization of the results of these studies with a systematic review is considered important in terms of being the source of future research and helping to spread the use of these technologies in education. Hence the purpose of this systematic review is to obtain a better understanding of how Web 3.0 technologies can be used to enhance quality of educational settings. Thus, information can be provided on how the evolution of web technologies will be reflected in educational environments. Because it is expected to move to Web 4.0 after 2020. Web 4.0 is called a symbiotic network in which the human mind can interact with the machine (Dominic, Francis \& Pilomenraj, 2014). Although the definition and characteristics of Web 4.0 are determined, it is not known how it will affect our daily lives and especially educational environments. It is thought that this study will shed light on future learning environments by examining the studies using Web 3.0 technologies in teaching. In addition, it was determined that these studies were generally focused on one of the Web 3.0 technologies (Ibanez, Delgado-Kloos, 2018; Reisoglu, Topu, Yilmaz, Yilmaz \& Goktas, 2017). In this study, more than one Web 3.0 tools are discussed and the researches in the literature are included in review. The purpose of this study is to review articles involving the use of Web 3.0 technologies in learning environments in a systematic way. For this purpose, the following sub-problems were sought:

1. What was the distribution of reviewed studies by years which determine the usage of Web 3.0 in learning environments?

2. In which disciplines were the reviewed studies carried out?

3. What were the trends in the use of research design of reviewed studies which determine the usage of Web 3.0 in learning environments?

4. What were the trends of data collecting tools, participants and examined variables of reviewed studies which determine the usage of Web 3.0 in learning environments?

\section{BACKGROUND OF THE STUDY}

Web 3.0 is also called "semantic web". Web 3.0 is a term created to describe the interaction that involves the development of Web use and the conversion of the Web into a database (Naik ve Shivalingaiah, 2008). With Web 3.0, computers can define what the query means when searching and what user intentions and needs are in this query (Miranda et al., 2014). Web 3.0 is called semantic web because it creates meaningful information. Because in these environments, the data is found by the software tools, evaluated and converted into meaningful information for transmission. With these tools, we can access the meaningful information we want in a personalized way for us in one step. The prominent features of these technologies are; smart web with intelligence analysis, personalization, interoperability web, virtualization (virtual 3D environments) and multimedia (Wadhwa, 2015). The widespread use of Web 3.0 technologies has been reflected in educational environments and has led to the development of e-learning 3.0. Dominic et al. (2014) and Rajiv and Lal (2011) summarized the E-learning 3.0 applications that provide individuals with personal settings and different options related to the use of Web 3.0 in education as Figure 1. 


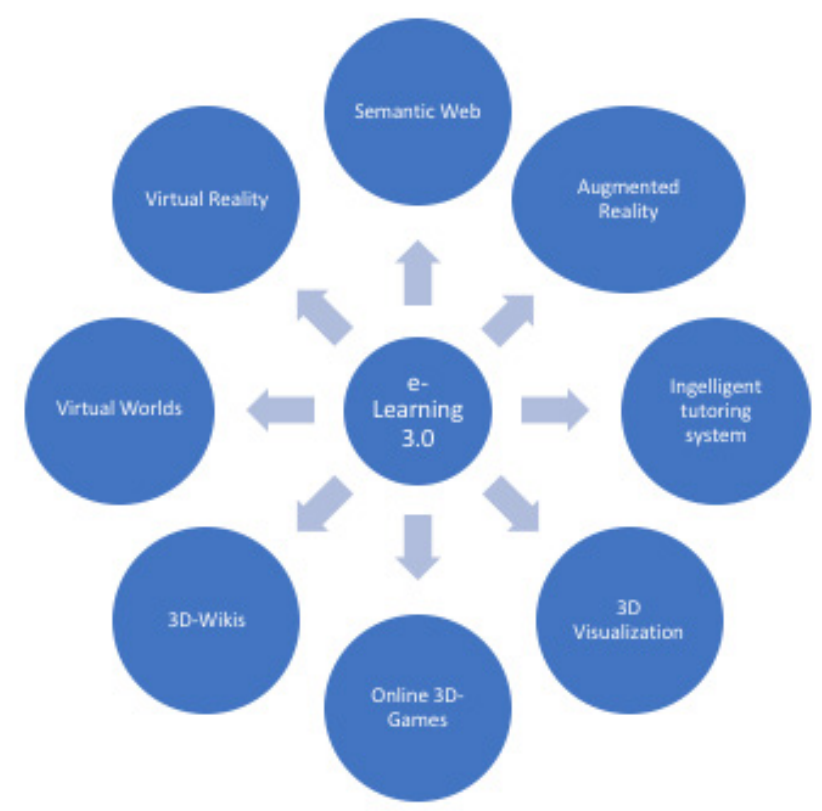

Figure 1. Web 3.0 Tools in E-learning (Dominic et al. 2014; Rajiv \& Lal, 2011)

When the tools in Figure 1 are examined, it is seen that most tools include three-dimensional (3D) visualization. Such software allows visualization of three-dimensional (3D) data and provides an interactive environment that enhances the feeling of immersion in the computer-generated virtual world (Huang, Rauch \& Liawc, 2010). In these environments, for example, a photo-realistic image of a 3D molecule can create a perception of looking at a real molecule, or a molecule can be rotated at a 360-degree angle to display different bond angles (Merchant, Goetz, Cifuentes, Keeney-Kennicutt \& Davis, 2014). Another frequently used tool is Augmented reality (AR) applications. Augmented reality (AR) refers to technologies that dynamically combine real-world environments and context-based digital information (Sommerauer \& Muller, 2014). Augmented Reality (AR) is the technology to add virtual objects to real scenes by allowing missing information to be added in real life (El Sayed, Zayed \& Sharawy, 2011). ARs can be used for educational purposes by combining with Web 2.0 technologies or Web 3.0 technologies. For example; Schmalstieg, Langlotz and Billinghurst (2011) used Web 2.0 technologies for AR software and allowed collaboration, communication and information sharing with the system they developed. Matuszka (2013) ise combine Semantic Web and Augmented Reality utilizing the benefits of combination of Augmented Reality applications. However, many studies have identified AR as an application of Web 3.0 technologies (ChisegaNegrilă, 2016; Delgado, Fonseca \& David, 2012; Dominic, Francis \& Pilomenraj, 2014; Kuhn, 2014; Norman, Din \& Nordin, 2011). The striking point in these studies is that the augmented reality applications go beyond the Web 2.0 tools that support communication and information sharing because they contain features for user intentions. Dominic et al. (2014), stated that Web 2.0 is about social networking and collaboration between creator and user; Web 3.0 is called smart web or semantic web with technologies such as big data, connected data, 3D visualization, augmented reality, and thus they incorporated augmented reality applications into Web 3.0 technologies. Chisega-Negrilă (2016) has similarly stated that the difference between Web 3.0 and Web 2.0 will be in the use of smart assistants who will provide augmented reality, text translation custom content (old, disabled) for specific categories of people. Accordingly, these tools, such as mobile learning, augmented reality (AR) are new ways to access information and provide potential for the Web 3.0 teaching concept (Delgado et al., 2012). Dominic et al. (2014) also stated that E-learning 3.0 technologies include augmented reality applications.

In this research, augmented reality applications are considered as a Web 3.0 technology based on these studies and are included in the systematic review. Another Web 3.0 tool is the Intelligent tutoring system (ITS). Intelligent Special Education Systems (ITSs) are computer-based education systems that shape teaching according to the individual learning needs of students and aim to reproduce the behavior of a teacher 
(Moundridou \& Virvou, 2003). ITS are teaching systems with an expert system that helps students solve a problem, and these systems mimic the interaction between the teacher who is an expert in a particular area and a student who wants to learn the concepts of that area (Nussbaum, Rosas, Peirano \& Cardenas, 2001). Therefore, ITSs have the ability to flexibly present teaching materials and provide feedback to students (Moundridou \& Virvou, 2003).

Web 3.0 tools use ontologies to make information structured and meaningful. Computer science borrows the term ontology from a branch of philosophy (metaphysics) that examines the nature of "existence" and enables the target world (or interpretation) to be represented in a comprehensible way by the computer (Isotani et al., 2013). In short, to realize the semantic Web, the use of ontology and conceptualization in organizing concepts and metadata are required. In semantic Web, ontology is a document or file containing a taxonomy and inference rules describing the concepts and their relationships that may exist for a particular field to enable information sharing and reuse (Huang \& Yang, 2009; Lee, Tsai \& Wang, 2008). An ontology explains concepts (classes) in a field, as well as relationships between these concepts (properties) (Huang \& Yang, 2009). From an information-based system perspective, ontology is considered a hierarchical network in which the concepts of nodes, arches or arrows represent the existing relationships between relevant concepts (Wang, Mendori \& Xiong, 2014). Ontologies have reusability, reasoning ability and support inference mechanisms that help provide advanced recommendations (George \& Lal, 2019).

\section{Web 3.0 and Education}

In these tools, an assistant is assisted by users who are interested in learning, choosing the necessary information and tailoring it to their individual learning needs (Chisega-Negrilă, 2013). With all these features, Web 3.0 technologies provide online support to trainers in situations such as improving their courses, providing student support, evaluating and keeping records (Morris, 2011). Thus, in Web 3.0 environments, the focus is shifted to the student with fully self-directed and self-regulating with semantic web Technologies (Wadhwa, 2015). Thus, in these environments, students play an active role in the formation of knowledge through learnercentered instruction. Therefore, with the help of smart environments and personal assistants provided in Web 3.0, individuals can organize their own learning, set goals and make decisions about their own learning (Chisega-Negrilă, 2013). For example; Students' interaction in 3D visual environments enables users to influence the occurrence of events in the virtual environment through their actions (Merchant et al., 2012). The teaching environments presented in these environments also support the paradigm of constructivism, which argues that individuals construct information individually and socially. Hussain (2012) reported how Web 3.0 technologies support the basic principles of constructivism as shown in Table 1 .

Table 1. Web 3.0 technologies supported by basic principles of connectivism.

\begin{tabular}{|c|c|}
\hline Web 3.0 technologies used in e-Learning 3.0 & Basic principles of connectivism \\
\hline Social semantic networks, openness and interoperability & Learning and knowledge rests in diversity of opinions. \\
\hline $\begin{array}{l}\text { Big data or global data repository, linked data, cloud } \\
\text { computing, extended smart mobile technology }\end{array}$ & $\begin{array}{l}\text { Learning is a process of connecting specialized nodes or } \\
\text { information sources. Currency of knowledge is important. }\end{array}$ \\
\hline $\begin{array}{l}\text { Machine learning, artificial intelligence, personal avatars, } \\
\text { 3D visualization and interaction }\end{array}$ & Learning may reside in non-human appliances. \\
\hline Semantic web, control of information & $\begin{array}{l}\text { Capacity to know more is more critical than what is currently } \\
\text { known. }\end{array}$ \\
\hline Semantic web, collaborative intelligent filtering & $\begin{array}{l}\text { Ability to see connections between fields, ideas, and concepts } \\
\text { is a core skill. }\end{array}$ \\
\hline Semantic web, collaborative intelligent filtering & $\begin{array}{l}\text { Nurturing and maintaining connections is needed to facilitate } \\
\text { continual learning. }\end{array}$ \\
\hline
\end{tabular}


As can be seen in Table 1, the features that semantic Web brings to teaching environments contribute to the implementation of constructivist teaching. Despite all of these contributions, there are challenges regarding the use of Web 3.0 technologies in education. Chisega-Negrilă (2013) explains the reasons for this situations; Security problems, Disliking changes, Not being innovative, No need for technology, Not familiar with technology, Disliking the idea of virtual assistants, Thinking that they will not have control over the process, Not trusting the information given, Choosing interaction with people, not making virtual decisions, Choosing to make your own decisions and so on. Hussain (2012) stated that, as a result of his literature study, some of the challenges are: "Increased privacy and security risks, Web accessibility, Readiness of the users, be it the learner or the tutor, Requirement for further standardization of e-Learning Technologies, and social issues in term of increase of the digital divide". In order to eliminate these challenges and to make effective use of Web 3.0 tools in educational processes, it is important to examine the studies in this literature.

\section{METHOD}

This study aimed to review the studies related to the use of Web 3.0 technologies in education by a systematic way. A systematic review is a review of a clearly formulated problem that uses systematic and open methods to identify, select and critically evaluate the research involved, and to collect and analyze data from the studies included in the review (Moher, Liberati, Tetzlaff \& Altman, 2009). Systematic analysis process was carried out using PRISMA Statement.

\section{Eligibility Criteria and Information Sources}

For the purpose of the study, firstly, articles published in English in peer-reviewed journals on the use of Web 3.0 in education as inclusion criteria were included. In order to determine the scope of the research, based on the Web 3.0 technologies specified by Dominic et al. (2014), and Rajiv and Lal (2011), semantic, augmented reality, intelligent tutoring system, $3 \mathrm{~d}$ visual environments, $3 \mathrm{~d}$ games and ontologies forming the infrastructure of these tools were included in the study. In the second stage, the criterion of the studies to be published in Computers and Education was determined. Computers and Education were chosen because it is one of the most cited journals in the field of educational technologies with 7.72 citeScore and 5.627 impact factors. In addition, when the top list of journals is analyzed according to Google Scholar Metrics, this journal is first in the Social Sciences category ranks, Educational Technology subcategories with $94 \mathrm{~h} 5$ index and $135 \mathrm{~h} 5$-median scores. For this reason, the systematic analysis was conducted by including only the studies published in this journal. Since the use of Web 3.0 technologies in education does not go back to very old years, all publications were handled without limitation for a certain year. In addition, since the PRISMA Statemant was proposed for the systematic review in the Computers and Education, the PRISMA Checklist was used in the research and report generation process and presented in this direction.

\section{Search}

Scopus and Science direct databases were used in the search in accordance with the criteria determined in the research. The search was made on 14-15 October 2019. Firstly Scopus search by using the following search criteria in accordance with the criteria mentioned above. During the search, only the title, summary or keywords were searched.

TITLE-ABS-KEY ( "web 3.0" OR "semantic" OR “intelligent tutoring system” OR "3d visual” OR ontology OR "augmented reality”) AND education AND ( LIMIT-TO ( SRCTYPE, “j”)) AND ( LIMIT-TO ( SUBJAREA, "SOCI") OR LIMIT-TO ( SUBJAREA, "COMP”) ) AND ( LIMIT-TO ( DOCTYPE, "ar")) AND ( LIMIT-TO ( EXACTSRCTITLE, "Computers And Education")) AND ( LIMIT-TO ( LANGUAGE, "English")) AND ( LIMIT-TO ( EXACTKEYWORD, "Ontology") OR LIMIT-TO ( EXACTKEYWORD, "Semantics") OR LIMIT-TO ( EXACTKEYWORD , "Semantic Web” ) OR LIMIT-TO ( EXACTKEYWORD, "Article") )

As a result of this search, 19 articles were reached. However, it was decided that the journal should be 
searched from the journal page of Computers and Education due to the low number of the studies. Following the steps of Computers and Education / View Articles / All Issues, a search was made through the Science Direct database. (https://www.sciencedirect.com/journal/computers-and-education/issues). While searching through Science Direct database, and / or tips did not work like Scopus, separate searches were performed for each Web 3.0 technology (web 3.0, semantic, ontology, intelligent tutoring system, 3d virtual, augmented reality) and full text file of articles were downloaded.

\section{Study Selection and Data Collection Process}

The inclusion and exclusion criteria used for the study selection in the study are as in Table 2 .

Table 2. Inclusion criteria and exclusion criteria

\begin{tabular}{|c|c|}
\hline Inclusion Criteria & Exclusion criteria \\
\hline $\begin{array}{l}\text { - Related to Web } 3.0 \text { in education. } \\
\text { - Related to semantic, augmented reality, intelligent } \\
\text { tutoring system, } 3 \mathrm{~d} \text { visual environments, } 3 \mathrm{~d} \text { games and } \\
\text { ontologies. } \\
\text { - Peer-reviewed journal article. } \\
\text { - Available with full-text. } \\
\text { - Published with English Language } \\
\text { - All research methods used in educational research were } \\
\text { included in the study. }\end{array}$ & $\begin{array}{l}\text { - Except articles published in journals other than } \\
\text { Computers and education. } \\
\text { - Studies whose research method is not clearly stated. } \\
\text { - Review and meta-analysis studies were excluded. } \\
\text { - Ontologies were excluded. }\end{array}$ \\
\hline
\end{tabular}

A pilot form was created to determine the studies to be included in the study and each study was examined by two researchers, and decided according to the criterias. In addition, in order to avoid bias risk in individual studies, all data analyzes were conducted separately by two researchers and discussed in non-common coding.

\section{RESULTS}

\section{Study selection}

The research process carried out in accordance with the determined criteria is summarized in Figure 2. 

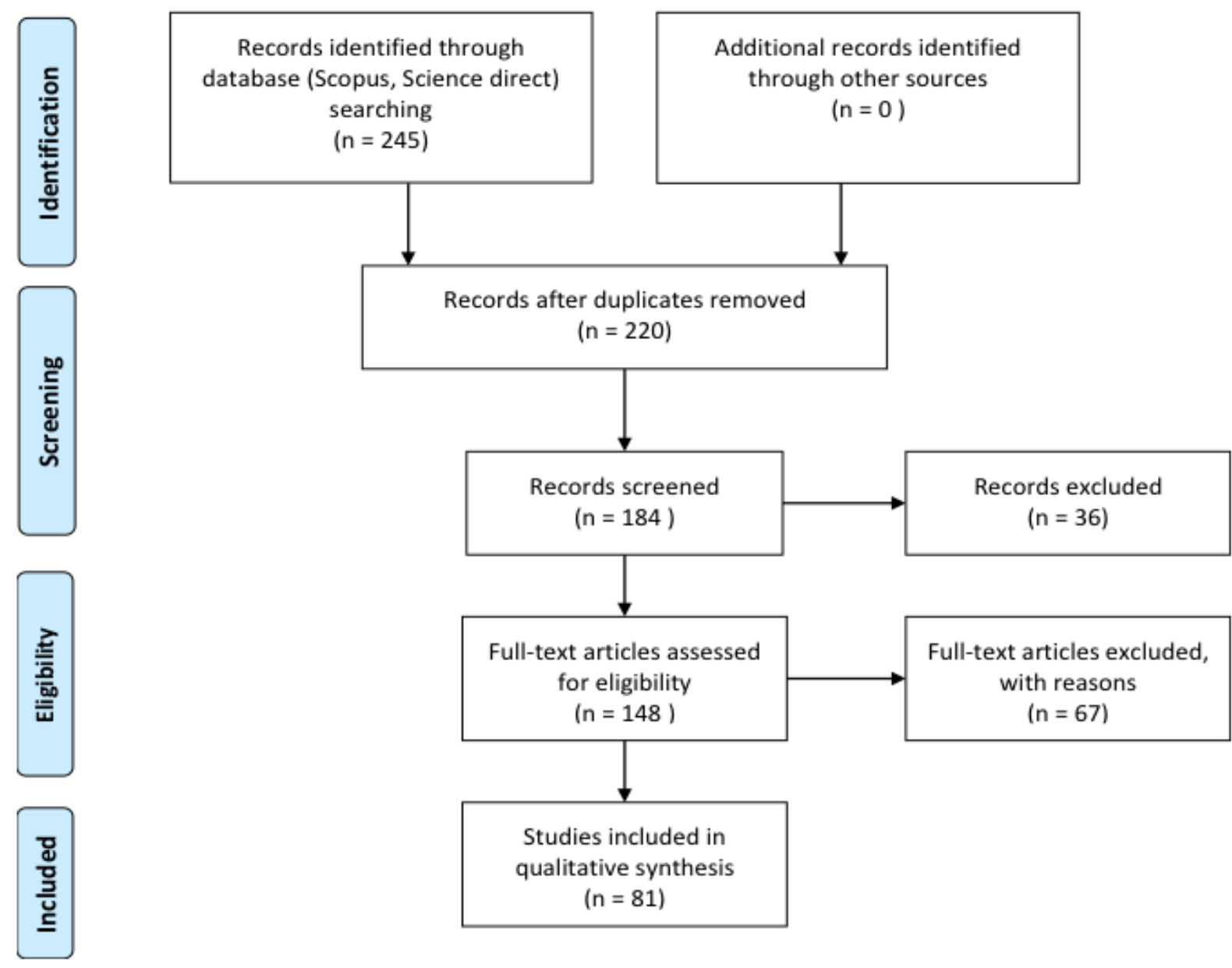

Figure 2. PRISMA Flow Diagram

Figure 2 shows the number of studies that were screened, assessed for eligilibility, included in or excluded from the systematic review.

\section{Study Characteristics}

Table 3 presents the studies included in the systematic review and which Web 3.0 browser these studies are related to.

Table 3. Studies in review and relevant Web 3.0 technologies

\begin{tabular}{ll}
\hline Web 3.0 technologies & Studies \\
\hline Semantic web & $\begin{array}{l}\text { Bujak et al., 2013; Isotani et al., 2013; Huang \& Yang, 2009; Lee, Tsai \& Wang, 2008; Lei, Sun, Lin \& } \\
\text { Huang, 2015; Vega-Gorgojo et al., 2010 }\end{array}$ \\
\hline & $\begin{array}{l}\text { Chen, 2016; Hamalainen \& Oksanen, 2012; Harker-Schuch, Mills, Lade \& Colvin, 2020; Korakakis, } \\
\text { 3D virtual }\end{array}$ \\
& $\begin{array}{l}\text { Pavlatou, Palyvos, \& Spyrellis, 2009; Merchant et al., 2012; Mzoughi, Herring, Foley, Morris \& } \\
\text { Zydney, deNoyelles, \& Seo, 2012; Wu \& Chiang, 2013 }\end{array}$ \\
\hline
\end{tabular}




\begin{tabular}{ll}
\hline $\begin{array}{l}\text { Augmented Reality/ } \\
\text { Virtual reality }\end{array}$ & Arici, Yildirim, Caliklar \& Yilmaz, 2019; Bouta, Retalis \& Paraskeva, 2012; Bujak at al., 2013; Chang \\
& et al., 2014; Chang \& Hwang, 2018; Chang, Lee, Wang \& Chen, 2010; Chen \& Tsai, 2012; Connolly, \\
& Stansfield \& Hainey, 2011; Cheng \& Tsai, 2014; Chiang, Yang \& Hwang, 2014; Cuendet, Bonnard, \\
& Do-Lenh \& Dillenbourg, 2013; Degli Innocenti et al., 2019; Di Serio, Ibanez \& Kloos, 2013; Hu- \\
& ang, Chen \& Chou, 2016; Ferguson, van den Broek \& van Oostendorp, 2020; Fidan \& Tuncel, \\
& 2019; Frank \& Kapila, 2017; Hsu, 2017; Huang, Rauch \& Liaw, 2010; Ibanez, Di Serio, Villaran \& \\
& Kloos, 2014; Ibanez \& Delgado-Kloos, 2018; Joo-Nagata, Abad, Giner \& Garcia-Penalvo, 2017; \\
& Kamarainen et al., 2013; Lin, Duh, Li, Wang \& Tsai, 2013; Lee \& Wong, 2014; Lindgren, Tscholl, \\
& Wang \& Johnson, 2016; Merchant et al.; Passig, Tzuriel \& Eshel-Kedmi, 2016; Rau, Zheng, Guo \& \\
& Li, 2018; Ruiz-Ariza, Casuso, Suarez-Manzano \& Martinez-Lopez, 2018; Sayed, Zayed \& Sharawy, \\
& 2011; Sahin \& Yilmaz, 2020; Sommerauer \& Muller, 2014; Zhang, Sung, Hou \& Chang, 2014; Wo- \\
& jciechowski \& Cellary, 2013; Wang, 2017; Wei, Weng, Liu \& Wang, 2015; Wu, Lee, Chang \& Liang, \\
& 2013; Yip, Wong, Yick, Chan \& Wong, 2019 \\
\hline Intelligent & Arnau, Arevalillo-Herraez, Puig \& Gonzalez-Calero, 2013; Chen, 2008; Chrysafiadi \& Virvou, 2013; \\
system & Curilem, Barbosa \& de Azevedo, 2007; Dangsaart, Naruedomkul, Cercone \& Sirinaovakul, 2008; \\
& Dolenc \& Abersek, 2015; He, Hui \& Quan, 2009; Hooshyar et al., 2016; Huang, Chu \& Guan, 2007; \\
& Huang, Liu, Chu \& Cheng, 2007; Hwang, 2003; Jaques \& Vicari, 2007; Latham, A., Crockett \& \\
& McLean, 2014; Latham, Crockett, McLean \& Edmonds, 2012; Mitrovic, Ohlsson \& Barrow, 2013; \\
& Mohamed \& Lamia, 2018; Moundridou \& Virvou, 2003; Nussbaum et al., 2001; Pavlekovic, Ze- \\
& kic-Susac \& Djurdjevic, 2009; Rau, Michaelis \& Fay, 2015; Sanchez, Bartel, Brown \& DeRosier, \\
& 2014; Vaessen, Prins \& Jeuring, 2014; Virvou \& Alepis, 2005; Waalkens, Aleven \& Taatgen, 2013; \\
& Wijekumar, Meyer \& Lei, 2013 \\
\hline
\end{tabular}

Table 3 shows all the studies in the systematic review. The distribution of these studies in terms of the relevant Web 3.0 technologies is shown in Figure 3.

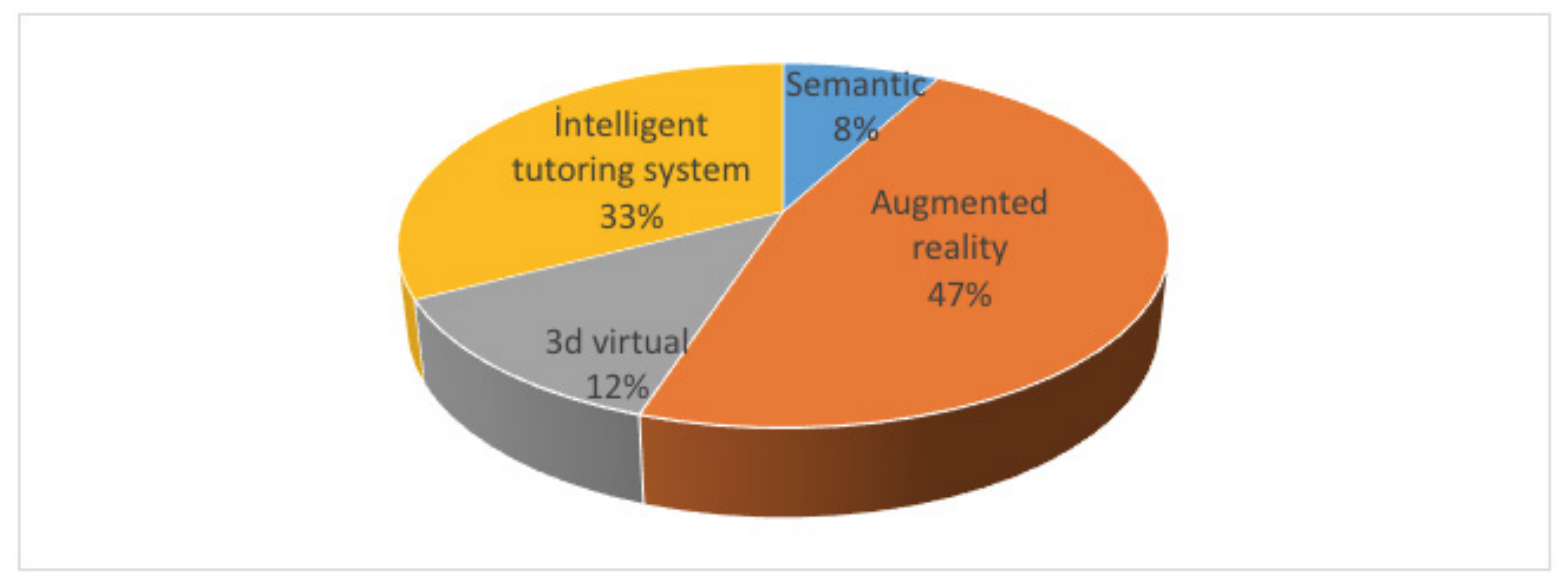

Figure 3. The distributions of studies

When Figure 3 was examined, it was found that the majority of the studies $(47 \%)$ discussed in the review were conducted in Augmented reality applications. In the second place, while $33 \%$ of the studies in intelligent tutoring systems, $12 \%$ of the studies in $3 \mathrm{~d}$ virtual technologies and semantic web technologies constitute $8 \%$.

\section{Results of the First sub Problem}

The first problem of the research is "What is the distribution of reviewed studies by years which determine the usage of Web 3.0 in learning environments?". The distribution of the reviewed studies by years is examined in the graph in Figure 4. 


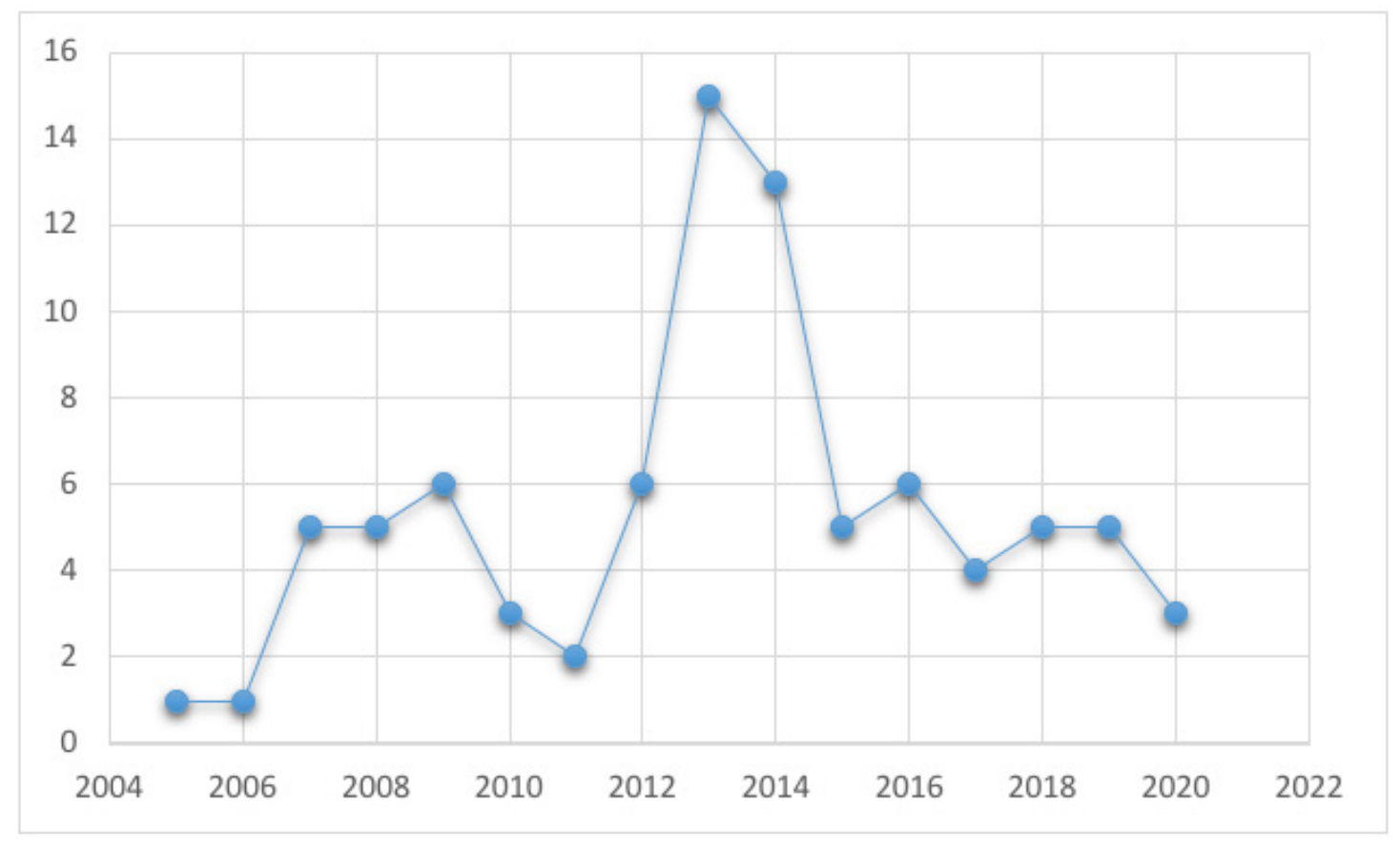

Figure 4. Distribution of the reviewed studies by years

When the distribution of the researches by years is examined, it has been observed that there has been an increase in 2008-2009 and a decrease in the number of studies in 2011. Furthermore, it was observed an increase again in 2013, but after 2015, the number of studies decreased again.

\section{Results of the Second sub Problem}

The second problem of the research is "In which disciplines were the reviewed studies carried out?". Distribution of the disciplines of reviewed studies is presented in Figure 5.

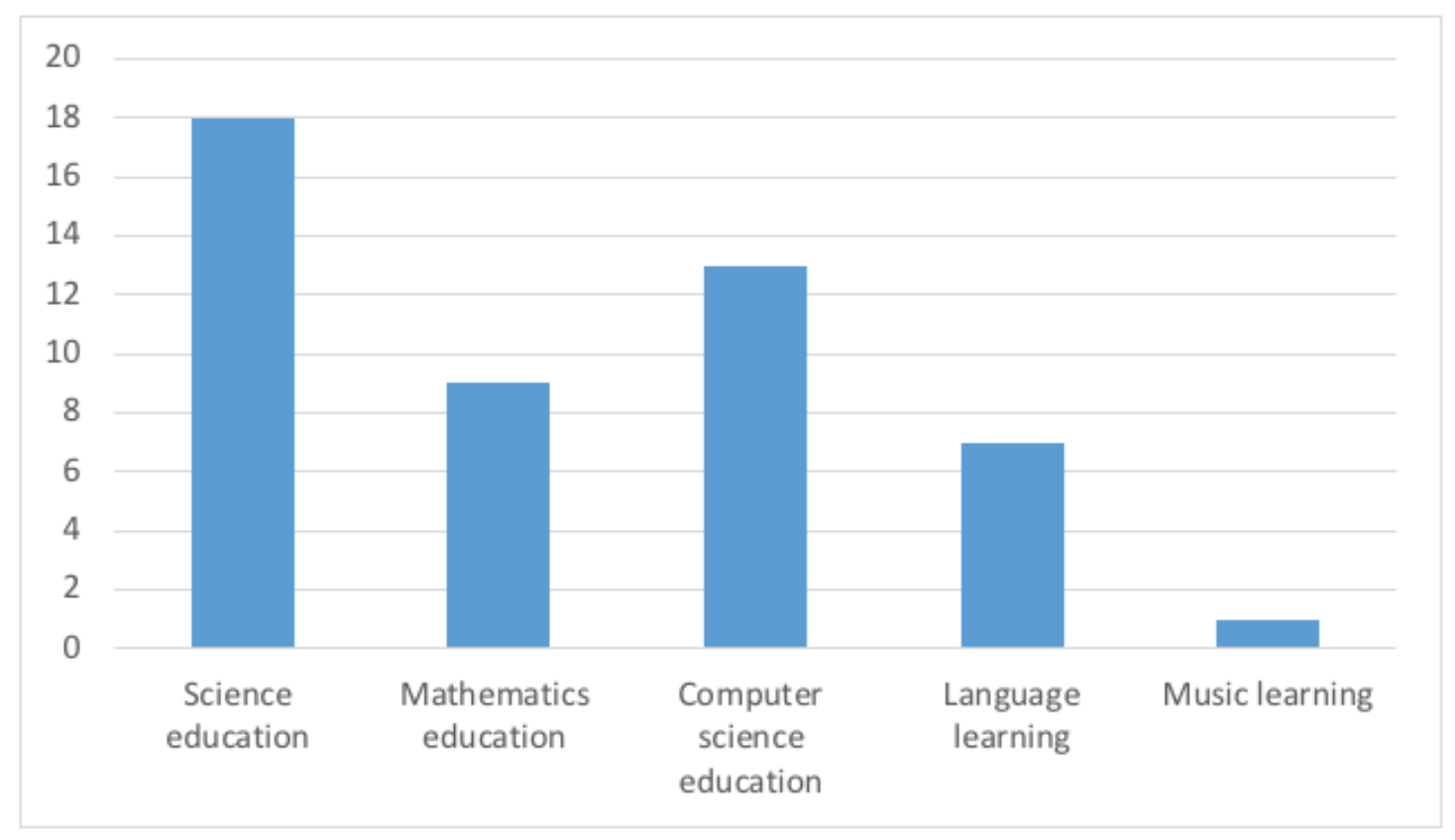

Figure 5. Distribution of the reviewed studies by disciplines 
When the studies were reviewed, it was determined that $22 \%$ of the studies were conducted in order to contribute to the field of science education. While $16 \%$ of the studies were conducted in the computer science education discipline, it was found that there were 9 studies in mathematics education and 7 studies in language learning. Furthermore, it was determined that $40 \%$ of the studies were not specific to any discipline but were made to contribute to learning/teaching environments.

\section{Results of the Third sub Problem}

The third problem of the research is "What were the trends in the use of research design of reviewed studies which determine the usage of Web 3.0 in learning environments?". Distribution of the research designs of reviewed studies is presented in Figure 6.

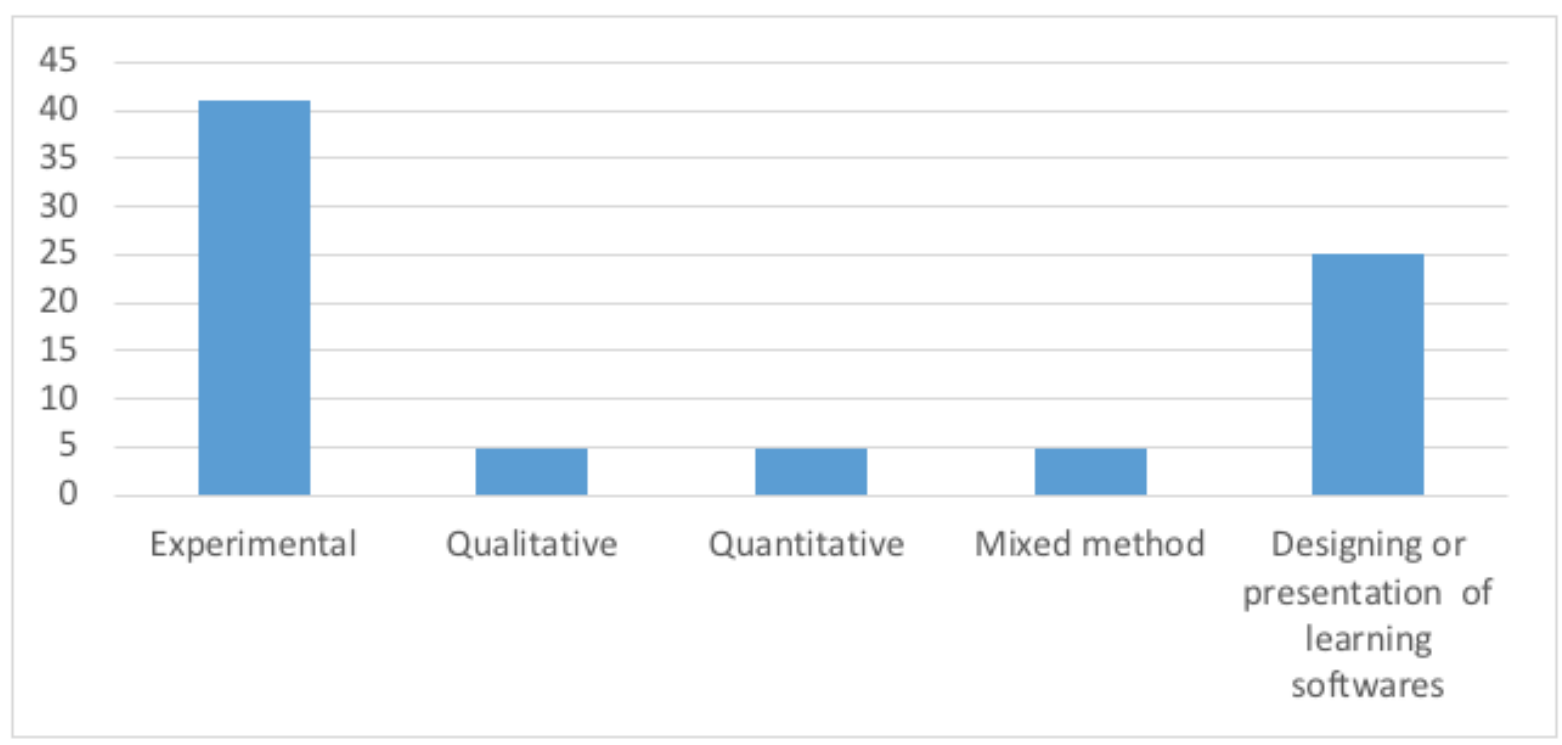

Figure 6. Distribution of the research designs of reviewed studies

Figure 6 shows that the majority of the studies $(n=41, \% 51)$ were conducted experimentally. The number of quantitative studies performed outside the experimental method is 5 and few studies $(n=5)$ were conducted qualitatively. In addition, the number of studies for designing or presentation of learning software was 25 .

\section{Results of the Fourth sub Problem}

The third problem of the research is "What were the trends of data collecting tools, participants and examined variables of reviewed studies which determine the usage of Web 3.0 in learning environments?". Table 4 shows participants, data collecting tools, and examined variables of reviewed studies.

Table 4. Participants, data collecting tools, and examined variables of reviewed studies

\begin{tabular}{llll}
\hline Studies & Participants & Data collection & Examined variables \\
\hline $\begin{array}{l}\text { Mzoughi et al., } \\
2007\end{array}$ & 386 university students & $\begin{array}{l}\text { Getting feedback from } \\
\text { instructors and student } \\
\text { surveys }\end{array}$ & Attitude \\
\hline $\begin{array}{l}\text { Korakakis et al., } \\
2009\end{array}$ & $\begin{array}{l}\text { 212 8th grade students } \\
\text { students in Greece }\end{array}$ & $\begin{array}{l}\text { With computer program } \\
\text { results exported to excel. }\end{array}$ & $\begin{array}{l}\text { The contribution to the learning } \\
\text { process of interactive 3D animations, } \\
\text { 3D animations and 3D illustrations }\end{array}$ \\
\hline
\end{tabular}




\begin{tabular}{|c|c|c|c|}
\hline $\begin{array}{l}\text { Sun \& Cheng, } \\
2009\end{array}$ & $\begin{array}{l}\text { Thirty undergraduate } \\
\text { students participated in } \\
\text { the study }\end{array}$ & Survey & $\begin{array}{l}\text { Perceived ease uf use, perceived } \\
\text { usefulness, attitude toward using } \\
\text { program, system usage, perceived } \\
\text { playfulness, interface style }\end{array}$ \\
\hline $\begin{array}{l}\text { Zydney et al., } \\
2012\end{array}$ & $\begin{array}{l}\text { Participants were } \\
21 \text { undergraduate } \\
\text { communications majors, } \\
\text { ranging in age from } 18 \text { to } \\
24 \text { years, }\end{array}$ & $\begin{array}{l}\text { Two surveys including both } \\
\text { closed and open-ended } \\
\text { questions. }\end{array}$ & $\begin{array}{l}\text { Group cognition, student ownership } \\
\text { of the discussion }\end{array}$ \\
\hline $\begin{array}{l}\text { Hamalainen, R., } \\
\text { \& Oksanen, } \mathrm{K} \text {. }\end{array}$ & $\begin{array}{l}18(16-18 \text {-year-old }) \\
\text { vocational students and } \\
\text { two teachers }\end{array}$ & $\begin{array}{l}\text { Video record Observation } \\
\text { notes }\end{array}$ & $\begin{array}{l}\text { Differences between the learning } \\
\text { settings in terms of time used and } \\
\text { knowledge construction processes }\end{array}$ \\
\hline $\begin{array}{l}\text { Merchant et al., } \\
2012\end{array}$ & $\begin{array}{l}238 \text { undergraduates } \\
\text { students }\end{array}$ & $\begin{array}{l}\text { Chemistry learning test, } \\
\text { the Purdue Visualization of } \\
\text { Rotations Test (PVRT), and a } \\
\text { self-report measure consisting } \\
\text { of items on six variables }\end{array}$ & $\begin{array}{l}\text { Representational fidelity, learners' } \\
\text { interaction, perceived ease of use and } \\
\text { meaningfulness, self-efficacy, and } \\
\text { presence }\end{array}$ \\
\hline $\begin{array}{l}\text { Wu \& Chiang, } \\
2013\end{array}$ & $\begin{array}{l}120 \text { freshmen ( } 72 \text { male, } 48 \\
\text { female, age M 20) from two } \\
\text { universities in Taiwan }\end{array}$ & Survey & $\begin{array}{l}\text { Comprehensive ability, the degree of } \\
\text { difficulty, and gender. }\end{array}$ \\
\hline $\begin{array}{l}\text { Richards \& } \\
\text { Taylor, } 2015\end{array}$ & 129 biology students & Pre and post test surveys & $\begin{array}{l}\text { Gender, age, level of computing skills } \\
\text { and } \\
\text { computer game usage. how often they } \\
\text { played computer games }\end{array}$ \\
\hline $\begin{array}{l}\text { Tuzun \& } \\
\text { Ozdinc, } 2016\end{array}$ & $\begin{array}{l}55 \text { freshmen students in a } \\
\text { Computer Education and } \\
\text { Instructional Technology }\end{array}$ & $\begin{array}{l}\text { 27-item Presence } \\
\text { Questionnaire in Virtual } \\
\text { Environments, the 18-item } \\
\text { Conceptual Knowledge Test, } \\
\text { the } 15 \text {-item Orientation } \\
\text { Evaluation Questionnaire, } \\
\text { the Spatial Knowledge } \\
\text { Inventory, and a demographic } \\
\text { questionnaire. }\end{array}$ & $\begin{array}{l}\text { Knowledge of the department's } \\
\text { objectives, locations, personnel and } \\
\text { such relevant information, factors of } \\
\text { influence on general learning, perceived } \\
\text { usefulness, enjoyment and complexity } \\
\text { users' perceptions of presence in virtual } \\
\text { environments Gender, university } \\
\text { entrance examination scores, and high } \\
\text { school grades. }\end{array}$ \\
\hline Chen, 2016 & 15 English learners & $\begin{array}{l}\text { Questionnaire Learner journals } \\
\text { Focus group interview } \\
\text { Participant observation }\end{array}$ & $\begin{array}{l}\text { Demographic backgrounds, digital } \\
\text { competency, engagement, motivation } \\
\text { expectations of learning English, } \\
\text { learners' beliefs and perceptions }\end{array}$ \\
\hline $\begin{array}{l}\text { Zhang et al., } \\
2014\end{array}$ & 200 fifth-grade students & $\begin{array}{l}\text { The learning achievement test } \\
\text { Stargazing targets test The } \\
\text { flow experience test }\end{array}$ & $\begin{array}{l}\text { Knowledge of astronomical } \\
\text { observations, performance of } \\
\text { astronomical observation skills, Flow } \\
\text { experience questionnaire and retention } \\
\text { effect }\end{array}$ \\
\hline $\begin{array}{l}\text { Lindgren et al., } \\
2016\end{array}$ & $\begin{array}{l}113 \text { seventh grade } \\
\text { students (age } 12 \text { to } 13 ; \\
47 \text { male, } 66 \text { female) from } \\
\text { three local middle schools }\end{array}$ & Pre-post test & Learning and attitude about science \\
\hline $\begin{array}{l}\text { Passig et al., } \\
2016\end{array}$ & $\begin{array}{l}117 \text { children ( } 61 \text { boys } \\
\text { and } 56 \text { girls) from two } \\
\text { elementary schools }\end{array}$ & Pre-post and transfer test & Improvement of analogies \\
\hline $\begin{array}{l}\text { Huang et al., } \\
2010\end{array}$ & 190 university students & Questionnaire & $\begin{array}{l}\text { Motivation, problem solving capacity, } \\
\text { imagination, interaction, immersion, } \\
\text { collaborative learning, intention to use } \\
\text { the system }\end{array}$ \\
\hline $\begin{array}{l}\text { Chang et al., } \\
2010\end{array}$ & $\begin{array}{l}36 \text { eight-grade students in } \\
\text { a rural public junior high } \\
\text { school in Taiwan }\end{array}$ & Questionnaire & $\begin{array}{l}\text { Learning performance, difference } \\
\text { in the subjective experience } \\
\text { (authenticity, engagement, learning } \\
\text { motivation) }\end{array}$ \\
\hline $\begin{array}{l}\text { Connolly et al., } \\
2011\end{array}$ & $\begin{array}{l}328 \text { students from } 28 \\
\text { schools across } 17 \text { European } \\
\text { countries }\end{array}$ & Questionnaire & $\begin{array}{l}\text { Demographic and learner type data, } \\
\text { details of foreign languages learnt, } \\
\text { skills that students believe can be } \\
\text { obtained from computer games, } \\
\text { important reasons and motivations for } \\
\text { playing computer games }\end{array}$ \\
\hline
\end{tabular}




\begin{tabular}{|c|c|c|c|}
\hline $\begin{array}{l}\text { Bouta et al., } \\
2012\end{array}$ & $\begin{array}{l}24 \text { children ( } 15 \text { boys and } \\
9 \text { girls), 5th grade Primary } \\
\text { School students }\end{array}$ & $\begin{array}{l}\text { Chat messages (obtained from } \\
\text { the logfiles of ActiveWorlds), } \\
\text { systematic observation of the } \\
\text { video-recorded sessions two- } \\
\text { stage assessment (pre-test } \\
\text { and post-test) }\end{array}$ & $\begin{array}{l}\text { Behavioral engagement, affective } \\
\text { engagement, cognitive engagement. }\end{array}$ \\
\hline $\begin{array}{l}\text { Chen \& Tsai, } \\
2012\end{array}$ & $\begin{array}{l}116 \text { Grade } 3 \text { student } \\
\text { from five classes at Taipei } \\
\text { Municipal Wanxing } \\
\text { Elementary School }\end{array}$ & $\begin{array}{l}\text { Group Embedded Figures } \\
\text { Test (GEFT), pretest-post } \\
\text { test, gaming skill quesionare, } \\
\text { learning satisfaction } \\
\text { questionnaire }\end{array}$ & $\begin{array}{l}\text { Learner performance, cognitive style, } \\
\text { gaming skill, and learner satisfaction }\end{array}$ \\
\hline $\begin{array}{l}\text { Di Serio et al., } \\
2013\end{array}$ & $\begin{array}{l}69 \text { middle-school students } \\
\text { (age 13-16) }\end{array}$ & $\begin{array}{l}\text { Instructional Materials } \\
\text { Motivation Survey (IMMS) } \\
\text { observing students interacting } \\
\text { with the augmented reality } \\
\text { learning environment and } \\
\text { conducting post-experience } \\
\text { interviews. }\end{array}$ & $\begin{array}{l}\text { Motivation (Attention, Relevance, } \\
\text { Confidence and Satisfaction) }\end{array}$ \\
\hline $\begin{array}{l}\text { Wojciechowski } \\
\text { \& Cellary, } 2013\end{array}$ & $\begin{array}{l}42 \text { participants of the } \\
\text { second grade of lower } \\
\text { secondary school at the } \\
\text { age of } 14-16 \text { years }\end{array}$ & Questionnaire & $\begin{array}{l}\text { Perceived usefulness and enjoyment, } \\
\text { perceived ease of use, attitude toward } \\
\text { using, interface style }\end{array}$ \\
\hline $\begin{array}{l}\text { Kamarainen et } \\
\text { al., } 2013\end{array}$ & Sixth grade students $(n=71)$ & Questionnaire & $\begin{array}{l}\text { Students' learning and motivation, and } \\
\text { teachers' experiences }\end{array}$ \\
\hline Lin et al., 2013 & $\begin{array}{l}20 \text { dyads }(\mathrm{N}=40) \text { of } \\
\text { undergraduate students } \\
\text { from a university located in } \\
\text { Singapore }\end{array}$ & Pre-post test & $\begin{array}{l}\text { Learning achievements, knowledge } \\
\text { construction process }\end{array}$ \\
\hline $\begin{array}{l}\text { lbanez et al., } \\
2014\end{array}$ & 64 high school students & $\begin{array}{l}\text { Pre-post test, Flow State } \\
\text { Scale and open-ended } \\
\text { questionnaires, survey }\end{array}$ & $\begin{array}{l}\text { Students' challenge-skill perception, } \\
\text { overall state of flow, students' learning } \\
\text { outcomes, students' perceived } \\
\text { benefits and difficulties of using an AR } \\
\text { application }\end{array}$ \\
\hline $\begin{array}{l}\text { Chang et al., } \\
2014\end{array}$ & 135 college students & $\begin{array}{l}\text { Pen-and-paper pretests and } \\
\text { posttests }\end{array}$ & $\begin{array}{l}\text { Learning effectiveness, flow } \\
\text { experience, the amount of time spent } \\
\text { focusing on the paintings, behavioral } \\
\text { patterns, and attitude of using the } \\
\text { guide systems }\end{array}$ \\
\hline $\begin{array}{l}\text { Cheng \& Tsai, } \\
2014\end{array}$ & 33 child-parent pairs & Videotape, interview & $\begin{array}{l}\text { Children and parents behave and } \\
\text { interaction with each other, cognitive } \\
\text { attainment of children, associations } \\
\text { between child-parent behavioral } \\
\text { patterns and children's cognitive } \\
\text { attainment }\end{array}$ \\
\hline $\begin{array}{l}\text { Chiang et al., } \\
2014\end{array}$ & $\begin{array}{l}57 \text { fourth-grade stu- } \\
\text { dents }\end{array}$ & Learning logs & Learning behaviors, learning patterns \\
\hline $\begin{array}{l}\text { Lee \& Wong, } \\
2014\end{array}$ & $\begin{array}{l}431 \text { high } \\
\text { school students }\end{array}$ & 32 item test & $\begin{array}{l}\text { Learners' performance achievement, } \\
\text { learners' spatial ability with the } \\
\text { learning environment }\end{array}$ \\
\hline Wei et al., 2015 & $\begin{array}{l}\text { T1 is the control group } \\
\text { and T2 is the experimental } \\
\text { group. T1 comprises } 8 \\
\text { boys and } 8 \text { girls, and T2 } \\
\text { comprises } 9 \text { boys and } 8 \\
\text { girls }\end{array}$ & Questionnare & $\begin{array}{l}\text { Creative design learning motivation, } \\
\text { teaching effects, and creativity of the } \\
\text { output }\end{array}$ \\
\hline $\begin{array}{l}\text { Huang et al., } \\
2016\end{array}$ & 21 middle school students & $\begin{array}{l}\text { Questionnare, pen-ended } \\
\text { interview survey }\end{array}$ & $\begin{array}{l}\text { Impact of different learning tools on } \\
\text { feelings, activity performance and } \\
\text { learning effectiveness. }\end{array}$ \\
\hline Hsu, 2017 & $\begin{array}{l}\text { A total of } 38 \text { third graders } \\
\text { whose average age was } \\
\text { nine }\end{array}$ & Questionnaire & $\begin{array}{l}\text { Students'learning effectiveness, flow } \\
\text { state, learning anxiety, and cognitive } \\
\text { load }\end{array}$ \\
\hline
\end{tabular}




\begin{tabular}{|c|c|c|c|}
\hline $\begin{array}{l}\text { Frank \& Kapila, } \\
2017\end{array}$ & $\begin{array}{l}75 \text { undergraduate } \\
\text { students }\end{array}$ & $\begin{array}{l}\text { Pre-post assesment test, } \\
\text { questionnaire }\end{array}$ & $\begin{array}{l}\text { Educational effectiveness and user } \\
\text { experience (sability, learnability, and } \\
\text { engagement) }\end{array}$ \\
\hline $\begin{array}{l}\text { Joo-Nagata et } \\
\text { al., } 2017\end{array}$ & $\begin{array}{l}143 \text { subjects of which } \\
72 \text { participated in the } \\
\text { fieldwork (m-learning) } \\
\text { and } 71 \text { in classroom work } \\
\text { (e-learning). }\end{array}$ & Pre-post test, interview & $\begin{array}{l}\text { Level of knowledge acquired by } \\
\text { students about heritage }\end{array}$ \\
\hline Wang, 2017 & 30 twelfth-grade students & $\begin{array}{l}\text { Pre-post questionnaries, } \\
\text { interview }\end{array}$ & $\begin{array}{l}\text { Students' Chinese writing } \\
\text { performance, students' and instructors' } \\
\text { perceptions of using AR-based } \\
\text { learning materials in Chinese writing }\end{array}$ \\
\hline $\begin{array}{l}\text { Ruiz-Ariza et al., } \\
2018\end{array}$ & $\begin{array}{l}\text { Control Group }(n=103) \\
\text { and Experimental Group } \\
(n=87)\end{array}$ & $\begin{array}{l}\text { Trait and Emotional } \\
\text { Intelligence Questionnaire } \\
\text { Short Form, pokemon go } \\
\text { game statistics, questionaire, } \\
\text { sociodemographic sheet. } \\
\text { Maternal educational level }\end{array}$ & $\begin{array}{l}\text { Cognitive perfor- mance (memory, } \\
\text { selective attention, concentration, } \\
\text { mathematical calculation and lin- } \\
\text { guistic reasoning) and emotional } \\
\text { intelligence (well-being, self-control, } \\
\text { emotionality and sociability }\end{array}$ \\
\hline $\begin{array}{l}\text { Chang \& } \\
\text { Hwang, } 2018\end{array}$ & 111 fifth graders & $\begin{array}{l}\text { Pre test, pre-questionnaires, } \\
\text { online learning ability test, } \\
\text { post test, post questionare, } \\
\text { interview }\end{array}$ & $\begin{array}{l}\text { Learning achievement, learning } \\
\text { motivation, critical thinking tendency, } \\
\text { group self-efficacy, cognitive load }\end{array}$ \\
\hline Rau et al., 2018 & 63 college students & Chinese Proficiency Test & Reading performance \\
\hline Yip et al., 2019 & 46 freshmen & $\begin{array}{l}\text { Pretest, post test, } \\
\text { questionnaire }\end{array}$ & $\begin{array}{l}\text { Learning outcomes, effectiveness of } \\
\text { AR, }\end{array}$ \\
\hline $\begin{array}{l}\text { Degli Innocenti } \\
\text { et al., } 2019\end{array}$ & $\begin{array}{l}36,10-11 \text { years old } \\
\text { children }\end{array}$ & Pre-post test, questionare & $\begin{array}{l}\text { Learning achievements, } \\
\text { students'perceived effort, } \\
\text { engagement, motivation, and } \\
\text { appreciation }\end{array}$ \\
\hline $\begin{array}{l}\text { Fidan \& Tuncel, } \\
2019\end{array}$ & $\begin{array}{l}91 \text { students (aged from } 12 \\
\text { to } 14 \text { seventh grade }\end{array}$ & $\begin{array}{l}\text { Learning achievement test, } \\
\text { Attitude scale, Interview form }\end{array}$ & $\begin{array}{l}\text { Physics learning achievement and } \\
\text { attitude in science course, opinions } \\
\text { of the students who used AR about } \\
\text { the impact of physics-related AR } \\
\text { applications on their learning } \\
\text { experiences }\end{array}$ \\
\hline $\begin{array}{l}\text { Ferguson et al., } \\
2020\end{array}$ & $\begin{array}{l}\text { A total of } 42 \text { adolescents, } \\
38 \text { males and } 4 \text { females, } \\
\text { aged } 13-17 \text {. }\end{array}$ & $\begin{array}{l}\text { Short knowledge test, } \\
\text { Standardized questionnaires }\end{array}$ & $\begin{array}{l}\text { The spatial and factual knowledge, } \\
\text { engagement, presence, and cognitive } \\
\text { interest }\end{array}$ \\
\hline $\begin{array}{l}\text { Harker-Schuch } \\
\text { et al., } 2020\end{array}$ & 401 students $12-13$ aged & Pre-post questionnaries & $\begin{array}{l}\text { Individual student scores, Climate } \\
\text { literacy }\end{array}$ \\
\hline $\begin{array}{l}\text { Sahin \& Yilmaz, } \\
2020\end{array}$ & $\begin{array}{l}1007 \text { th grade middle } \\
\text { school students }\end{array}$ & $\begin{array}{l}\text { Science Course Achievement } \\
\text { Test", the "Attitude Towards } \\
\text { Science Course Scale" and } \\
\text { the "Attitude to- wards AR } \\
\text { Activities Scale" }\end{array}$ & Academic achievement, attitudes \\
\hline $\begin{array}{l}\text { Huang \& Yang, } \\
2009\end{array}$ & $\begin{array}{l}136 \text { first-year (freshmen) } \\
\text { undergraduate students }\end{array}$ & Pre-post test & $\begin{array}{l}\text { Learning performance, adaptive } \\
\text { learning performance collaborative } \\
\text { activities, satisfaction with system } \\
\text { (students' perceptions), knowledge } \\
\text { types }\end{array}$ \\
\hline $\begin{array}{l}\text { Isotani et al., } \\
2013\end{array}$ & $\begin{array}{l}\text { Fifty eight (58) pre-service } \\
\text { teachers }\end{array}$ & $\begin{array}{l}\text { Think-aloud protocol and } \\
\text { explicitly ask teachers to } \\
\text { explain as much as possible } \\
\text { every decision they } \\
\text { made. }\end{array}$ & Teacher's intentions and performance \\
\hline Lei et al., 2015 & 100 Taiwanese fifth graders & $\begin{array}{l}\text { Questionnare, search behavior } \\
\text { indicators, Video search } \\
\text { worksheet }\end{array}$ & $\begin{array}{l}\text { Search behaviors, search performance, } \\
\text { and learning performance }\end{array}$ \\
\hline
\end{tabular}




\begin{tabular}{|c|c|c|c|}
\hline $\begin{array}{l}\text { Chrysafiadi \& } \\
\text { Virvou, } 2013\end{array}$ & $\begin{array}{l}128 \text { teachers and their } \\
5 \text { th grade students, } 131 \\
\text { teachers and their } 4 \text { th } \\
\text { grade classrooms }\end{array}$ & $\begin{array}{l}\text { Pre- and post-test and two } \\
\text { forms of a researcher designed } \\
\text { measure }\end{array}$ & Reading comprehension \\
\hline $\begin{array}{l}\text { Vaessen et al., } \\
2014\end{array}$ & $\begin{array}{l}210 \text { students of the } \\
\text { University of Utrech }\end{array}$ & $\begin{array}{l}\text { Achievement Goal } \\
\text { Questionnaire }\end{array}$ & $\begin{array}{l}\text { Help-seeking behavior, Identified } \\
\text { help-seeking strategies, The use of } \\
\text { strategies in relation to students and } \\
\text { exercises, Predicted strategy use by } \\
\text { achievement goals }\end{array}$ \\
\hline $\begin{array}{l}\text { Sanchez et al., } \\
2014\end{array}$ & $\begin{array}{l}36 \text { participants via postings } \\
\text { on local parenting listservs, } \\
\text { social media sites, and } \\
\text { through contacts within } \\
\text { area school systems and } \\
\text { child service providers. }\end{array}$ & $\begin{array}{l}\text { Online product evaluation } \\
\text { survey., The Youth Outcomes } \\
\text { Questionnaire, the Behavioral } \\
\text { and Emotional Rating Scale }\end{array}$ & $\begin{array}{l}\text { Usability, Likeability, Psychosocial } \\
\text { distress, Behavioral and emotional } \\
\text { strength }\end{array}$ \\
\hline $\begin{array}{l}\text { Dolenc \& } \\
\text { Abersek, } 2015\end{array}$ & 8th grade 117 students & Online test & Student achivement \\
\hline $\begin{array}{l}\text { Hooshyar et al., } \\
2016\end{array}$ & 52 university students & Pre and post test & $\begin{array}{l}\text { Learning interest, technology } \\
\text { acceptance and learning attitude }\end{array}$ \\
\hline $\begin{array}{l}\text { Mohamed \& } \\
\text { Lamia, } 2018\end{array}$ & $\begin{array}{l}50 \text { learners at Annaba } \\
\text { University. }\end{array}$ & $\begin{array}{l}\text { Questionnaire, Performance } \\
\text { 7-point rating scale, Mental } \\
\text { effort 7-point rating scale, } \\
\text { Survey }\end{array}$ & $\begin{array}{l}\text { Student knowledge level, Learning } \\
\text { time, Learning gain, Mental effort }\end{array}$ \\
\hline
\end{tabular}

Some of the studies (Arnau et al., 2013; Bujak et al., 2013; Chen, 2008; Cuendet et al., 2013; Curilem et al., 2007; Dangsaart et al., 2008; He et al., 2009; Huang et al., 2007; Jaques \& Vicari, 2007; Latham et al., 2014; Lee et al., 2008; Mitrovic et al., 2013; Moundridou \& Virvou, 2003; Nussbaum et al., 2001; Pavlekovic et al., 2009; Sayed et al., 2011; Stankov et al., 2008; Vega-Gorgojo et al., 2010; Virvou \& Alepis, 2005; Waalkens et al., 2013; Wu, Lee, Chang \& Liang, 2013) included in the review and presented their findings in other sub-problems were not examined in Table 4, as they do not include any implementations and are only intended for software promotion or potential of softwares as a teaching/learning tool.

\section{DISCUSSION AND CONCLUSION}

In this study, 81 studies related to the use of Web 3.0 technologies in learning environments were reviewed by a systematic way. As a result of the reviewed studies, it was determined that the most studies related to the use of augmented/virtual reality applications in learning environments. The advantages of these tools, such as providing students with a natural experience environment and increasing the attractiveness of teaching and learning and increasing the motivation of the students (Sumadio, Dwistratanti \& Rambli, 2010), may have contributed to the researches on this concept. In addition, ease of use of these tools also facilitates the transfer to teaching environments. Another result of the study is that there has been an increase in the number of the studies in 2008-2009 and a decrease in the number of studies in 2011. Furthermore, it was observed an increase again in 2013, but after 2015, the number of studies decreased again. The increase in the number of studies in 2008 may be due to the extension of Tim Berners-Lee's definition of "execution" into web technologies in 2007, and web became a "read-write-execution" network of web services and semantic markup (Demartini \& Benussi, 2017). Thus, a jump in the number of studies has occurred.

When the studies were reviewed, it was determined that the highest number of studies were conducted in the field of science education. Digital resources, transformed into cognitive tools, can help science learners experiment and critically think about real-life events by working in controlled, hypothetical or virtual environments (Songer, 2007). Therefore, the fact that there are more studies in the field of science education is considered important in terms of providing scientific literacy which is the aim of science education and contributing to this discipline. Furthermore, it was found that there were 9 studies in mathematics education and 7 studies in language learning. 
Results shows that the majority of the studies $(n=41, \% 51)$ were conducted experimentally. Since experimental studies are the most conclusive of scientific methods (Fraenkel, Wallen \& Hyun, 2012), the fact that most of the studies are directed to experimental implementation of Web 3.0 technology may increase the validity of the researches. In addition, as a result of the analysis, it is seen that a few qualitative research is conducted. In addition, the number of studies for designing or presentation of learning softwares was 25 . Participants, data collection tools and examined variables of the reviewed studies were also examined in the study. When the participants of the researches are examined, it is seen that the studies are conducted with individuals at all educational level and at certain ages. Participation of the individuals from all grade level is considered important in terms of integrating Web 3.0 into learning environments at all levels of education. When the data collection tools used in the studies were examined, it was found that the majority of the studies were quantitative and most benefited from surveys, questionnaires and observational information in the data collection process. Some studies were conducted with mixed method and qualitative data were used in addition to quantitative data. It is considered important to collect qualitative data in order to explain the effects of using Web 3.0 technologies in learning environments in detail. Finally, the examined variables of the researches were examined. According to the results, it was determined that cognitive variables were generally focused in the researches. In addition, the majority of studies focus on the learning usefulness and learning outcomes of the software used in the research.

In conclusion, this study conducted a systematic review of 81 studies on the use of Web 3.0 technologies in learning environments. The data obtained from this study is thought to be a resource for instructors and researchers during the integration of Web 3.0 technologies into education. It also provides information on how to use web technologies in future learning environments. Because the evolution of the web and its reflection on learning environments are realized by moving forward with the exponential growth of the previous web technology. Since Web 4.0, which is expected to be passed after 2020, is not completely clear in the literature and does not provide unanimity due to the fact that it is composed of several dimensions, it is not yet known how web technologies will affect educational environments in the future (Almeida, 2017). The Education 4.0 profile barely enters the real-life scene, and today's most advanced technology, Education 3.0, together with sustainable learning paradigms, shows that it is a reasonable current scenario for education (Demartini \& Benussi, 2017). Therefore, this study, which includes the use of the latest web technologies in education, can shed light on future studies.

\section{Limitations and Implications}

This review doesn't include theses, conference proceedings and books. Furthermore reviewed articles related Web 3.0 technologies published in only Computers \& Education. It may be suggested that further studies on this subject can be examined by widening the scope by scanning from different sources, journals and databases with other studies. By expanding the databases used in this study, more factors can be revealed or the emerging factors can be supported with more frequency. In addition, this study was conducted within the framework of four sub-problems. Participants, data collection tools and examined variables of the reviewed studies were also examined in the study. Further systematic reviews with examined other factors such as the learning outcomes of the studies or the effectiveness of the tools will contribute to the literature.

In this research, many Web 3.0 technologies were handled together and literature will guide new researches as they provide resources for the use of these technologies in learning process. When the data were analyzed methodologically, it was determined that the paradigmatic evolution in the web was reflected in the researches after 2005, but it was determined that the studies with qualitative and mixed methods in this field were insufficient. Furthermore, most of the studies use experimental research methodology. A meta-analysis of these experimental studies can provide information about the effects of Web 3.0 tools on teaching processes. Therefore, in future studies, it can be suggested to perform meta-analyzes by calculating the effect sizes of the findings obtained from these experimental studies. Thus, more generalizable information can be obtained about the use of these technologies in teaching environments by increasing the number and diversity of samples.

When the studies discussed in this review are examined, the number of qualitative studies is very few. Although the quantitative methods carried out using the experimental method are used in testing the web 
supported learning environments, the opinions of all stakeholders about the developed teaching module are also important. Collecting data from stakeholders will help in eliminating practical problems in the teaching process. Thus, it will contribute to the quality of teaching process. Therefore, two situations gain importance for future studies. First of all, it is recommended to do more studies with qualitative and mixed methods in order to provide more detailed and in-depth information in the integration of Web 3.0 technologies into the teaching process (Patton, 1999). Secondly, when the studies in this study are examined, it is generally determined that data are collected from students. This situation may hinder multi-directional examination of the teaching process. Particularly, the opinions of teachers who play a key role in the teaching process are of great importance in the integration. Therefore, in the studies to be carried out, it is recommended to collect data from all stakeholders and perform triangulation in terms of methodology and data source.

In addition, the effectiveness of the technologies used was generally carried out within a certain time period in the studies examined. In order to use Web 3.0 technologies effectively in teaching processes, longitudinal studies should be carried out in the use of these technologies, and it should be noted that student / teacher / prospective teacher were observed in a long process and what kind of process they went through. Therefore, longitudinal studies are needed to talk about sustainability in the use of technologies used in educational context. In these studies to be conducted in the future, it is also recommended to use a large number of data collection tools such as observation and interview. Because in the studies examined in this review, it is determined that a single data collection tool was generally used and these sources are generally questionnaire or scale.

When the studies were reviewed, it was determined that the highest number of studies were conducted in the field of science education. It is remarkable that studies in Social Studies education are relatively less. In order to increase the use of Web 3.0 technologies in this field and to benefit from the contributions provides to the teaching environments, it is thought that more studies are needed in integrated Web 3.0 Social Studies education. Finally, according to the results, it was determined that cognitive variables were generally focused in the researches. In addition, the majority of studies focus on the learning usefulness and learning outcomes of the software used in the research. It can be investigated whether these web 3.0 technologies have a similar effect on different groups in terms of cognitive variables. In addition, in order to ensure the sustainability of usage of web 3.0 technologies in education, it is recommended to examine the emotional, social and behavioral variables in different sample groups as well as cognitive variables.

\section{BIODATA and CONTACT ADDRESSES of AUTHORS}

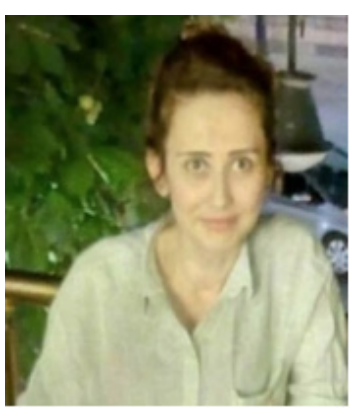

Dr. Esra ACIKGUL FIRAT is an assistant Professor of Mathematics and Science Education at Education Faculty, Adiyaman University. Dr. Acikgul Firat gained his Ph.D. in Science Education at September, 2015. Her academic interest areas are science education, Web 2.0 tools for science education, biotechnology education and computer assisted science education. She has international book chapters and various research articles published in international indexes. Also, she has other national and international articles and papers submitted to international meetings.

\section{Esra ACIKGUL FIRAT}

Mathematics and Science Education, Faculty of Education

Address: Adiyaman University, 02040, Adiyaman, Turkey

Phone: +90 4162233800 - 3415

E-mail: eacikgul@adiyaman.edu.tr 


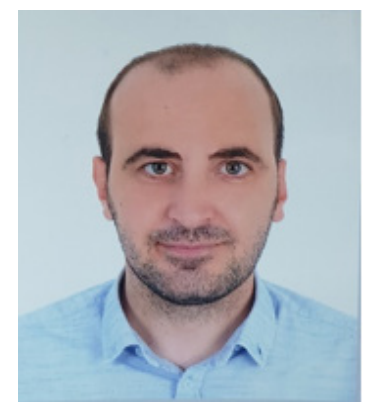

Selcuk FIRAT

Educational Sciences, Faculty of Education

Address: Adiyaman University, 02040, Adiyaman, Turkey

Phone: +904162233800 - 1069

E-mail: selcukfirat@adiyaman.edu.tr

\section{REFERENCES}

Almeida, F. L. (2017). Concept and dimensions of web 4.0. International Journal of Computers \& Technology, 16(7), 7040-7046.

Arici, F., Yildirim, P., Caliklar, S., \& Yilmaz, R. M. (2019). Research trends in the use of augmented reality in science education: Content and bibliometric mapping analysis. Computers \& Education, 142, 103647.

Arnau, D., Arevalillo-Herraez, M., Puig, L., \& Gonzalez-Calero, J. A. (2013). Fundamentals of the design and the operation of an intelligent tutoring system for the learning of the arithmetical and algebraic way of solving word problems. Computers \& Education, 63, 119-130.

Berners-Lee, T., Hendler, J., \& Lassila, O. (2001). The semantic web. Scientific american, 284(5), 28-37.

Bouta, H., Retalis, S., \& Paraskeva, F. (2012). Utilising a collaborative macro-script to enhance student engagement: A mixed method study in a 3D virtual environment. Computers \& Education, 58(1), 501-517.

Buffington, M. L. (2008). Creating and consuming Web 2.0 in art education. Computers in the Schools, 25(3-4), 303-313.

Bujak, K. R., Radu, I., Catrambone, R., Macintyre, B., Zheng, R., \& Golubski, G. (2013). A psychological perspective on augmented reality in the mathematics classroom. Computers \& Education, 68, 536-544.

Bujak, K. R., Radu, I., Catrambone, R., Macintyre, B., Zheng, R., \& Golubski, G. (2013). A psychological perspective on augmented reality in the mathematics classroom. Computers \& Education, 68, 536-544.

Chang, C. W., Lee, J. H., Wang, C. Y., \& Chen, G. D. (2010). Improving the authentic learning experience by integrating robots into the mixed-reality environment. Computers \& Education, 55(4), 1572-1578.

Chang, K. E., Chang, C. T., Hou, H. T., Sung, Y. T., Chao, H. L., \& Lee, C. M. (2014). Development and behavioral pattern analysis of a mobile guide system with augmented reality for painting appreciation instruction in an art museum. Computers \& Education, 71, 185-197.

Chang, S. C., \& Hwang, G. J. (2018). Impacts of an augmented reality-based flipped learning guiding approach on students' scientific project performance and perceptions. Computers \& Education, 125, 226-239.

Chen, C. M. (2008). Intelligent web-based learning system with personalized learning path guidance. Computers \& Education, 51(2), 787-814.

Chen, C. M., \& Tsai, Y. N. (2012). Interactive augmented reality system for enhancing library instruction in elementary schools. Computers \& Education, 59(2), 638-652.

Chen, J. C. (2016). The crossroads of English language learners, task-based instruction, and 3D multi-user virtual learning in Second Life. Computers \& Education, 102, 152-171. 
Cheng, K. H., \& Tsai, C. C. (2014). Children and parents' reading of an augmented reality picture book: Analyses of behavioral patterns and cognitive attainment. Computers \& Education, 72, 302-312.

Chiang, T. H., Yang, S. J., \& Hwang, G. J. (2014). Students' online interactive patterns in augmented reality-based inquiry activities. Computers \& Education, 78, 97-108.

Chisega-Negrilă, A. M. (2013). Education in Web 3.0. JADLET Journal of Advanced Distributed Learning Technology, 50-59.

Chisega-Negrila, A. M. (2016). Impact Of Web 3.0 on The Evolution Of Learning. In Conference proceedings of» eLearning and Software for Education «(eLSE) (No. 01, pp. 58-62)." Carol I" National Defence University Publishing House.

Chrysafiadi, K., \& Virvou, M. (2013). PeRSIVA: An empirical evaluation method of a student model of an intelligent e-learning environment for computer programming. Computers \& Education, 68, $322-333$.

Connolly, T. M., Stansfield, M., \& Hainey, T. (2011). An alternate reality game for language learning: ARGuing for multilingual motivation. Computers \& Education, 57(1), 1389-1415.

Cuendet, S., Bonnard, Q., Do-Lenh, S., \& Dillenbourg, P. (2013). Designing augmented reality for the classroom. Computers \& Education, 68, 557-569.

Curilem, S. G., Barbosa, A. R., \& de Azevedo, F. M. (2007). Intelligent tutoring systems: Formalization as automata and interface design using neural networks. Computers \& Education, 49(3), 545-561.

Dangsaart, S., Naruedomkul, K., Cercone, N., \& Sirinaovakul, B. (2008). Intelligent Thai text-Thai sign translation for language learning. Computers \& Education, 51(3), 1125-1141.

Degli Innocenti, E., Geronazzo, M., Vescovi, D., Nordahl, R., Serafin, S., Ludovico, L. A., \& Avanzini, F. (2019). Mobile virtual reality for musical genre learning in primary education. Computers \& Education, 139, 102-117.

Demartini, C., \& Benussi, L. (2017). Do Web 4.0 and industry 4.0 imply education X. 0?. IT Professional, 19(3), 4-7.

Di Serio, A., Ibanez, M. B., \& Kloos, C. D. (2013). Impact of an augmented reality system on students' motivation for a visual art course. Computers \& Education, 68, 586-596.

Dolenc, K., \& Abersek, B. (2015). TECH8 intelligent and adaptive e-learning system: Integration into Technology and Science classrooms in lower secondary schools. Computers \& Education, 82, 354365.

Dominic, M., Francis, S., \& Pilomenraj, A. (2014). E-learning in web 3.0. International Journal of Modern Education and Computer Science, 6(2), 8.

El Sayed, N., A. M., Zayed, H., \& Sharawy, M. I. (2011). ARSC: Augmented reality student card-an augmented reality solution for the education field. Computer \& Education, 56(4), 1045-1106.

Ferguson, C., van den Broek, E. L., \& van Oostendorp, H. (2020). On the role of interaction mode and story structure in virtual reality serious games. Computers \& Education, 143, 103671.

Fidan, M., \& Tuncel, M. (2019). Integrating augmented reality into problem based learning: The effects on learning achievement and attitude in physics education. Computers \& Education, 142, 103635.

Frank, J. A., \& Kapila, V. (2017). Mixed-reality learning environments: Integrating mobile interfaces with laboratory test-beds. Computers \& Education, 110, 88-104.

Fraenkel, W., \& Wallen, N. Hyun, (2012). How to design and evaluate research in education. McGraw-Hill Companies.

George, G., \& Lal, A. M. (2019). Review of ontology-based recommender systems in e-learning. Computers \& Education, 142, 103642.

Grosseck, G. (2009). To use or not to use web 2.0 in higher education?. Procedia-Social and Behavioral Sciences, 1(1), 478-482. 
Hamalainen, R., \& Oksanen, K. (2012). Challenge of supporting vocational learning: Empowering collaboration in a scripted $3 \mathrm{D}$ game-How does teachers' real-time orchestration make a difference?. Computers \& Education, 59(2), 281-293.

Harker-Schuch, I., Mills, F., Lade, S., \& Colvin, R. (2020). CO2peration-Structuring a 3D interactive digital game to improve climate literacy in the 12-13-year-old age group. Computers \& Education, $144,103705$.

He, Y., Hui, S. C., \& Quan, T. T. (2009). Automatic summary assessment for intelligent tutoring systems. Computers \& Education, 53(3), 890-899.

Hooshyar, D., Ahmad, R. B., Yousefi, M., Fathi, M., Horng, S. J., \& Lim, H. (2016). Applying an online game-based formative assessment in a flowchart-based intelligent tutoring system for improving problem-solving skills. Computers \& Education, 94, 18-36.

Hsu, T. C. (2017). Learning English with augmented reality: Do learning styles matter?. Computers \& Education, 106, 137-149.

Huang, C. J., Chu, S. S., \& Guan, C. T. (2007). Implementation and performance evaluation of parameter improvement mechanisms for intelligent e-learning systems. Computers \& Education, 49(3), 597-614.

Huang, C. J., Liu, M. C., Chu, S. S., \& Cheng, C. L. (2007). An intelligent learning diagnosis system for Web-based thematic learning platform. Computers \& Education, 48(4), 658-679.

Huang, H. M., Rauch, U., \& Liaw, S. S. (2010). Investigating learners' attitudes toward virtual reality learning environments: Based on a constructivist approach. Computers \& Education, 55(3), 11711182.

Huang, S. L., \& Yang, C. W. (2009). Designing a semantic bliki system to support different types of knowledge and adaptive learning. Computers \& Education, 53(3), 701-712.

Huang, T. C., Chen, C. C., \& Chou, Y. W. (2016). Animating eco-education: To see, feel, and discover in an augmented reality-based experiential learning environment. Computers \& Education, 96, 72-82.

Hussain, F. (2012). E-Learning 3.0= E-Learning 2.0+ Web 3.0?. International Association for Development of the Information Society.

Hwang, G. J. (2003). A conceptual map model for developing intelligent tutoring systems. Computers \& Education, 40(3), 217-235.

Ibanez, M. B., \& Delgado-Kloos, C. (2018). Augmented reality for STEM learning: A systematic review. Computers \& Education, 123, 109-123.

Ibanez, M. B., Di Serio, A., Villaran, D., \& Kloos, C. D. (2014). Experimenting with electromagnetism using augmented reality: Impact on flow student experience and educational effectiveness. Computers \& Education, 71, 1-13.

Isotani, S., Mizoguchi, R., Isotani, S., Capeli, O. M., Isotani, N., De Albuquerque, A. R., Bittencourt, I. I., \& Jaques, P. (2013). A Semantic Web-based authoring tool to facilitate the planning of collaborative learning scenarios compliant with learning theories. Computers \& Education, 63, 267-284.

Jaques, P. A., \& Vicari, R. M. (2007). A BDI approach to infer student's emotions in an intelligent learning environment. Computers \& Education, 49(2), 360-384.

Joo-Nagata, J., Abad, F. M., Giner, J. G. B., \& Garcia-Penalvo, F. J. (2017). Augmented reality and pedestrian navigation through its implementation in m-learning and e-learning: Evaluation of an educational program in Chile. Computers \& Education, 111, 1-17.

Kamarainen, A. M., Metcalf, S., Grotzer, T., Browne, A., Mazzuca, D., Tutwiler, M. S., \& Dede, C. (2013). EcoMOBILE: Integrating augmented reality and probeware with environmental education field trips. Computers \& Education, 68, 545-556.

Korakakis, G., Pavlatou, E. A., Palyvos, J. A., \& Spyrellis, N. (2009). 3D visualization types in multimedia applications for science learning: A case study for 8th grade students in Greece. Computers \& Education, 52(2), 390-401. 
Kuhn, V. (2014). Web three point oh: The virtual is the real. High Wired Redux: CyberText Yearbook. Jyvaskyla, Finland: University of Jyvaskyla Press, at http://cybertext. hum. jyu. fi/articles/155. pdf, accessed, 18.

Latham, A., Crockett, K., \& McLean, D. (2014). An adaptation algorithm for an intelligent natural language tutoring system. Computers \& Education, 71, 97-110.

Latham, A., Crockett, K., McLean, D., \& Edmonds, B. (2012). A conversational intelligent tutoring system to automatically predict learning styles. Computers \& Education, 59(1), 95-109.

Lee, E. A. L., \& Wong, K. W. (2014). Learning with desktop virtual reality: Low spatial ability learners are more positively affected. Computers \& Education, 79, 49-58.

Lee, M. C., Tsai, K. H., \& Wang, T. I. (2008). A practical ontology query expansion algorithm for semanticaware learning objects retrieval. Computers \& Education, 50(4), 1240-1257.

Lee, M. C., Tsai, K. H., \& Wang, T. I. (2008). A practical ontology query expansion algorithm for semanticaware learning objects retrieval. Computers \& Education, 50(4), 1240-1257.

Lei, P. L., Sun, C. T., Lin, S. S., \& Huang, T. K. (2015). Effect of metacognitive strategies and verbalimagery cognitive style on biology-based video search and learning performance. Computers \& Education, 87, 326-339.

Lin, T. J., Duh, H. B. L., Li, N., Wang, H. Y., \& Tsai, C. C. (2013). An investigation of learners' collaborative knowledge construction performances and behavior patterns in an augmented reality simulation system. Computers \& Education, 68, 314-321.

Lindgren, R., Tscholl, M., Wang, S., \& Johnson, E. (2016). Enhancing learning and engagement through embodied interaction within a mixed reality simulation. Computers \& Education, 95, 174-187.

Mansur, A. B. F., \& Yusof, N. (2013). Social learning network analysis model to identify learning patterns using ontology clustering techniques and meaningful learning. Computers \& Education, 63, 73-86.

Merchant, Z., Goetz, E. T., Cifuentes, L., Keeney-Kennicutt, W., \& Davis, T. J. (2014). Effectiveness of virtual reality-based instruction on students' learning outcomes in K-12 and higher education: A meta-analysis. Computers \& Education, 70, 29-40.

Merchant, Z., Goetz, E. T., Keeney-Kennicutt, W., Kwok, O. M., Cifuentes, L., \& Davis, T. J. (2012). The learner characteristics, features of desktop 3D virtual reality environments, and college chemistry instruction: A structural equation modeling analysis. Computers \& Education, 59(2), 551-568.

Miranda, P., Isaias, P., \& Costa, C. J. (2014). E-Learning and web generations: Towards Web 3.0 and E-Learning 3.0. International Proceedings of Economics Development and Research, 81, 92.

Mitrovic, A., Ohlsson, S., \& Barrow, D. K. (2013). The effect of positive feedback in a constraint-based intelligent tutoring system. Computers \& Education, 60(1), 264-272.

Mohamed, H., \& Lamia, M. (2018). Implementing flipped classroom that used an intelligent tutoring system into learning process. Computers \& Education, 124, 62-76.

Moher D, Liberati A, Tetzlaff J, Altman DG, The PRISMA Group (2009). Preferred Reporting Items for Systematic Reviews and Meta-Analyses: The PRISMA Statement. PLoS Med 6(7): e1000097. doi:10.1371/journal.pmed1000097

Morris, R. D. (2011). Web 3.0: Implications for online learning. TechTrends, 55(1), 42-46.

Moher D, Liberati A, Tetzlaff J, Altman DG, The PRISMA Group (2009). Preferred Reporting Items for Systematic Reviews and Meta-Analyses: The PRISMA Statement. PLoS Med 6(7): e1000097. Doi:10.1371/journal.pmed1000097

Moundridou, M., \& Virvou, M. (2003). Analysis and design of a web-based authoring tool generating intelligent tutoring systems. Computers \& Education, 40(2), 157-181.

Mzoughi, T., Herring, S. D., Foley, J. T., Morris, M. J., \& Gilbert, P. J. (2007). WebTOP: A 3D interactive system for teaching and learning optics. Computers \& Education, 49(1), 110-129.

Naik, U., \& Shivalingaiah, D. (2008). Comparative study of Web 1.0. In Web (Vol. 2, pp. 28-29). 
Navarro Delgado, I., \& Fonseca, D. (2012). Architecture Degree PRoject: USe of 3D Technology, Models and Augmented Reality Experience with Visually Impaired Users. Systemics, Cybernetics and Informatics, 10(2).

Norman, H., Din, R., \& Nordin, N. (2011). A preliminary study of an authentic ubiquitous learning environment for higher education. Learning, 3(4), 89-94.

Nussbaum, M., Rosas, R., Peirano, I., \& Cardenas, F. (2001). Development of intelligent tutoring systems using knowledge structures. Computers \& Education, 36(1), 15-32.

Passig, D. (2015). Revisiting the Flynn effect through 3D immersive virtual reality (IVR). Computers \& Education, 88, 327-342.

Passig, D., Tzuriel, D., \& Eshel-Kedmi, G. (2016). Improving children's cognitive modifiability by dynamic assessment in 3D Immersive Virtual Reality environments. Computers \& Education, 95, 296-308.

Park, S. W. (2013). The potential of web 2.0 tools to promote reading engagement in a general education course. TechTrends, 57(2), 46-53.

Patton, M. Q. (2002) Qualitative Research and Evaluation Methods. Thousand Oaks, CA: Sage Publications, Inc.

Pavlekovic, M., Zekic-Susac, M., \& Djurdjevic, I. (2009). Comparison of intelligent systems in detecting a child's mathematical gift. Computers \& Education, 53(1), 142-154.

Rajiv \& Lal, M. (2011). Web 3.0 in Education \& Research. BVICAM’s International Journal of Information Technology, 3.

Rau, M. A., Michaelis, J. E., \& Fay, N. (2015). Connection making between multiple graphical representations: A multi-methods approach for domain-specific grounding of an intelligent tutoring system for chemistry. Computers \& Education, 82, 460-485.

Rau, P. L. P., Zheng, J., Guo, Z., \& Li, J. (2018). Speed reading on virtual reality and augmented reality. Computers \& Education, 125, 240-245.

Reisoglu, I., Topu, B., Yilmaz, R., Yilmaz, T. K., \& Goktas, Y. (2017). 3D virtual learning environments in education: A meta-review. Asia Pacific Education Review, 18(1), 81-100.

Richards, D., \& Taylor, M. (2015). A Comparison of learning gains when using a 2D simulation tool versus a 3D virtual world: An experiment to find the right representation involving the Marginal Value Theorem. Computers \& Education, 86, 157-171.

Ruiz-Ariza, A., Casuso, R. A., Suarez-Manzano, S., \& Martinez-Lopez, E. J. (2018). Effect of augmented reality game Pokemon GO on cognitive performance and emotional intelligence in adolescent young. Computers \& Education, 116, 49-63.

Sahin, D., \& Yilmaz, R. M. (2020). The effect of Augmented Reality Technology on middle school students' achievements and attitudes towards science education. Computers \& Education, 144, 103710.

Sanchez, R. P., Bartel, C. M., Brown, E., \& DeRosier, M. (2014). The acceptability and efficacy of an intelligent social tutoring system. Computers \& Education, 78, 321-332.

Sayed, N. E., Zayed, H. H., \& Sharawy, M. I. (2011). ARSC: Augmented reality student card an augmented reality solution for the education field. Computers \& Education, 56(4), 1045-1061.

Sommerauer, P., \& Muller, O. (2014). Augmented reality in informal learning environments: A field experiment in a mathematics exhibition. Computers \& Education, 79, 59-68.

Songer, N. B. (2007). Digital resources versus cognitive tools: A discussion of learning. Handbook of research on science education, 471 .

Stankov, S., Rosic, M., Zitko, B., \& Grubisic, A. (2008). TEx-Sys model for building intelligent tutoring systems. Computers \& Education, 51(3), 1017-1036.

Sumadio, D. D., Dwistratanti, \& Rambli, D. R. A. (2010). Preliminary evaluation on user acceptance of the augmented reality use for education. In The second international conference on computer engineering and applications (pp. 461-465). 
Sun, H. M., \& Cheng, W. L. (2009). The input-interface of Webcam applied in 3D virtual reality systems. Computers \& Education, 53(4), 1231-1240.

Thomas, D. A., and Li, Q. (2008). From Web 2.0 to teacher 2.0. Computers in the Schools, 25(3-4), 199210.

Tuzun, H., \& Ozdinc, F. (2016). The effects of 3D multi-user virtual environments on freshmen university students' conceptual and spatial learning and presence in departmental orientation. Computers \& Education, 94, 228-240.

Vaessen, B. E., Prins, F. J., \& Jeuring, J. (2014). University students' achievement goals and help-seeking strategies in an intelligent tutoring system. Computers \& Education, 72, 196-208.

Vega-Gorgojo, G., Bote-Lorenzo, M. L., Asensio-Perez, J. I., Gomez-Sanchez, E., Dimitriadis, Y. A., \& JorrinAbellan, I. M. (2010). Semantic search of tools for collaborative learning with the Ontoolsearch system. Computers \& Education, 54(4), 835-848.

Virvou, M., \& Alepis, E. (2005). Mobile educational features in authoring tools for personalised tutoring. Computers \& Education, 44(1), 53-68.

Waalkens, M., Aleven, V., \& Taatgen, N. (2013). Does supporting multiple student strategies lead to greater learning and motivation? Investigating a source of complexity in the architecture of intelligent tutoring systems. Computers \& Education, 60(1), 159-171.

Wadhwa, D. (2015). A study of web 3.0 technologies for collaborative learning. International Journal of Engineering Technology, Management and Applied Sciences, 3, 92-97.

Wang, H. C., \& Hsu, C. W. (2006). Teaching-Material Design Center: An ontology-based system for customizing reusable e-materials. Computers \& Education, 46(4), 458-470.

Wang, J., Mendori, T., \& Xiong, J. (2014). A language learning support system using course-centered ontology and its evaluation. Computers \& Education, 78, 278-293.

Wang, Y. H. (2017). Exploring the effectiveness of integrating augmented reality-based materials to support writing activities. Computers \& Education, 113, 162-176.

Wei, X., Weng, D., Liu, Y., \& Wang, Y. (2015). Teaching based on augmented reality for a technical creative design course. Computers \& Education, 81, 221-234.

Wijekumar, K. K., Meyer, B. J., \& Lei, P. (2013). High-fidelity implementation of web-based intelligent tutoring system improves fourth and fifth graders content area reading comprehension. Computers \& Education, 68, 366-379.

Wojciechowski, R., \& Cellary, W. (2013). Evaluation of learners' attitude toward learning in ARIES augmented reality environments. Computers \& Education, 68, 570-585.

Wu, C. F., \& Chiang, M. C. (2013). Effectiveness of applying 2D static depictions and 3D animations to orthographic views learning in graphical course. Computers \& Education, 63, 28-42.

Wu, H. K., Lee, S. W. Y., Chang, H. Y., \& Liang, J. C. (2013). Current status, opportunities and challenges of augmented reality in education. Computers \& Education, 62, 41-49.

Yip, J., Wong, S. H., Yick, K. L., Chan, K., \& Wong, K. H. (2019). Improving quality of teaching and learning in classes by using augmented reality video. Computers \& Education, 128, 88-101.

Zeng, Q., Zhao, Z., \& Liang, Y. (2009). Course ontology-based user's knowledge requirement acquisition from behaviors within e-learning systems. Computers \& Education, 53(3), 809-818.

Zhang, J., Sung, Y. T., Hou, H. T., \& Chang, K. E. (2014). The development and evaluation of an augmented reality-based armillary sphere for astronomical observation instruction. Computers \& education, 73, $178-188$.

Zydney, J. M., deNoyelles, A., \& Seo, K. K. J. (2012). Creating a community of inquiry in online environments: An exploratory study on the effect of a protocol on interactions within asynchronous discussions. Computers \& Education, 58(1), 77-87. 